\title{
Studying of Russian Folk Tales in the Context of Intercultural Dialogue at Schools with (Non-Russian) Language Learning
}

\author{
Lera A. Kamalova ${ }^{1}$ \\ ${ }^{1}$ Kazan (Volga region) Federal University, Kazan, Russia \\ Correspondence: Lera A. Kamalova, Kazan (Volga region) Federal University, Kremlyovskaya Street 18, Kazan, \\ 420008, Russia. E-mail: leraax57@mail.ru
}

Received: December 29, 2014

Accepted: January 22, 2015 Online Published: February 11, 2015

doi:10.5539/res.v7n4p105

URL: http://dx.doi.org/10.5539/res.v7n4p105

\begin{abstract}
The relevance of this study is due to new approaches to of primary education system, other criteria knowledge and competences assessment of primary school students in literary reading. School practice and the introduction of national educational standards at primary school dictate the need of study of Russian folk tales in the context of the dialogue of cultures at schools with native (non-Russian) language of the Republic of Tatarstan. The purpose of this article is to research and develop science-based methods of 1 Russian and Tatar folk tales studying based on the dialogue of two cultures. A leading method of this problem study is a pedagogical experiment (ascertainment, formation and control stages) as well as the method of expert estimations, statistical processing of the quantitative results of the study. The main results of the research are the formation of new method of studying of Russian and Tatar folk tales at elementary school based on the dialogue of two cultures. The suggested methodical system of learning of Russian and Tatar folk fairy tales, household tales and tales about animals domestic, is effective, provides a deep knowledge of the younger students, the ability to analyze and compare Russian and Tatar folk tales on the subject, the ideological content of artistic features. The article can be useful for teachers of higher educational institutions and primary school teachers in the application of this technique to the study of Russian and Tatar folk tales in the context of dialogue of cultures.
\end{abstract}

Keywords: folk tale, fairy tale, fairy tale about animals, household tale, dialogue of cultures, methods, literary reading

\section{Introduction}

\subsection{Relevance of the Problem}

A lot of works on philosophy by Bibler (1999), Bakhtin (1986), Gachev (2009) on methods of literature teaching (Mukhametshina, 2006), on pedagogy (Akhmetzyanova, 2014) are dedicated to the problem of "dialogue of cultures"

Bibler understood the problem of the dialogue of cultures as "a communication of the actual and / or potential cultures". The scientist gave some evidences. First, "culture always exists in a simultaneous "space" of many cultures..." secondly, "the culture time is always currently, today communicate all past and future cultures..." third, "in this communication each culture realizes itself as a separate culture, a distinctive, rounded, and inexhaustible in its uniqueness and eternity." Fourth, the "dialogue of cultures... is like... the communion of persons" (Bibler, 1999). The Concept of C. S. Bibler gives an understanding of the "dialogue of cultures" as the communication of different cultures (cultures of thinking and understanding) and the process is endless deployment and formation of new meanings.

A. I. Akhmetzyanova emphasizes the importance of students' speech development, based on the level of space-time factor of speech development (Akhmetzyanova, 2014).

"Dialogue of cultures" is considered by scientists as a process of "creative understanding" of different cultures in time and space, as the clash and the correlation of different creative individualities, points of view. Studying of Russian folk tales in the context of "dialogue of cultures" is a new concept of literature educating which demands deep knowledge, ability to compare and match from students.

As a form of folklore Russian folk tales carry high moral principles, moral values and esthetic ideals of the nation. (Propp, 2000) 
A. N. Afanasyev writes: "The subject of telling was not a person not his social worries and feats but various phenomena of the whole nature" (Afanasyev, 1994).

Imaginations of ancient people about totem are reflected in myths and then in fairy tales about animals. Meletinskiy compares the tales and the myths from the view of influence of totemism on them.

Numerous totemic myths especially mythological anecdotes about tricksters are widely represented in fairy tales about the animals. Mythological genesis is seen in universal storylines of the fairy tale about the marriage with a miraculous "totemic creature, which dropped of its animal skin..." (Meletinskiy, 1976).

Studying of the Russian fairy tales at school solves one of the most important problems of humanization of the education, joining young generation to the sources of national culture and art.

By studying of the Russian folk tales in the context of the "dialogue of cultures" at school with native non Russian language it is necessary to take into account the peculiarities of understanding Russian folk tales by non Russian students, their esthetic tastes, national traditions and their national character traits.

Using of factors which show the identity of the phenomena in Russian and native cultures, their interrelation, comparing of Russian and Tatar works of folklore help to overcome the hardships which complicate the studying of Russian folk tales by non Russian students.

Wholeness and completeness, depth of understanding of this complicated material at schools with native (non Russian) language of studying depends on the ability to compare and match the works of Russian and native literature, to understand Russian folk tales as a phenomenon of native and world culture, which collected "national picture of the world" (Grachyov, 2009).

\subsection{Explore Importance of the Problem}

Literature course at school with non Russian language studying is based on the principles and demands, which are common for Russian and national schools. A wide range of specific principles which are typical for literature teaching at schools with non Russian language of studying are noticed in this research. They are:

- Necessity of taking into account the unequal levels of linguistic preparation of the students in different national regions;

- Originality of social, ethnographic and other environmental peculiarities of non Russian students, which affect literary text understanding

- National-art specific of native literature, folklore, which forms national-art thinking of students, individual-psychological peculiarities of understanding reality by people of different nationalities.

Using of comparing technique in the context of two cultures dialogue by the studying of the topic "Russian folk tales" activates the thinking activity of students, helps to set interrelation between the Russian and Tatar folk tales, to study the theoretical-literary concepts better and to develop of associated thinking and imagination, to understand the works deeper.

Orientation of teaching process on the "dialogue of cultures" helps to solve the problem of reading development of students, which is impossible without formation of certain reading abilities, without serious theoretical-literary preparation.

Comparing of Russian and Tatar folk tales allows solve the task of interpenetration of two cultures and accepting another culture by students without ignoring their own. Used comparing technique allows show common human content of national culture and national world character in Russian and Tatar folk tales.

The proposed methodological model allows study the characteristics of the fairy tale genre for example the mapping of Russian and Tatar folk tales.

\section{Materials and Methods}

\subsection{Objects of the Study}

The study solved the following tasks:

1) To research the works of theory and history of literature, philosophy, and pedagogy. psychology, theory and methods of teaching literature relevant to the research problem;

2) To theoretically substantiate foundations of the Russian folk tales study and ways of formation of the concept about the tales of elementary school with a native (non-Russian) language learning in the context of the dialogue of cultures; 
3) To develop a methodological model of formation of concepts about the Russian folk tales; to identify the features of perception tales by non Russian students; to determine the most effective methods of teaching;

4) To experimentally verify the effectiveness of the training by developed training model, to generalize the results of the experiment and make methodical recommendations about the study of Russian folk tales in elementary schools with native (non-Russian) language in the context of dialogue of cultures.

\subsection{Theoretical and Empirical Methods}

There has been used a complex of different methods which were complementary to each other for testing these hypothesis:

- Theoretical: analysis of the works of literary critics, philosophers, experts in aesthetics, teachers and psychologists on the issue of research; analysis of methodical and educational literature; theoretical analysis of the main provisions of the proposed method, on the basis of which was nominated the hypothesis of the study; theoretical justification of the educational model of concepts formation about the Russian folk tale in the context of the dialogue of cultures; study and synthesis of innovative pedagogical experience, analysis, synthesis;

- Empirical: observation studies, ascertaining and forming pedagogical experiment, questionnaires, tests, interviews, conversations, analysis of the results of experimental work.

\subsection{Basis for Research}

The basis of the study were "Grammar school No. 5" of Zelenodolsk, "Ayshinskaya school" of Zelenodolsk region, "Nurlat school", "Osinovskaya grammar school by Karpov", and "Vasilevskaya school No. 3" of Zelenodolsk region.

\subsection{Stages of the Research}

The study was provided in three stages:

On the first stage there were created experimental grounds on the basis of those schools in the Republic of Tatarstan, there was held the observation the teachers and students activity at the lessons of folk tales reading; questionnaire and interviews with teachers and students; establishment of formation levels of General concepts about the Russian folk tale of the pupils at schools with native (non-Russian) language of studying, was approbated the research theme at the initial stage of experiment ascertaining.

On the second stage was refined and adjusted the theoretical concept of the study was performed a mass training experiment in the elementary grades of the schools of the Republic of Tatarstan: at Grammar school №5, Ayshinskaya secondary school, Nurlat Secondary school, Osinovskaya school by Karpov and Vasilyevskaya Grammar school.

On the third stage, was made the analysis, generalization and systematization of the data, the design of the study; carried out the testing of the research themes in publications and speeches of the author at scientific conferences.

\subsection{Evaluation Criteria}

Evaluation of the effectiveness of Russian folk tales studying in the context of the dialogue of cultures at schools with native (non-Russian) studying language of the Republic of Tatarstan was held using the following criteria:

- Development level of Russian national tale concept by primary school students as a measure of the degree of literary concepts development and reading skills of students in the context of the dialogue of cultures;

- Creative development level of primary classes students as a measure of the degree of philological development of students in the context of the dialogue of cultures;

\subsection{The Course and Description of the Experiment}

In the process of ascertaining stage of experiment was made diagnostics of formation level of concepts about the Russian folk magic, house holding tales and tales about animals by primary school students with native (non-Russian) language.

The purpose of this experiment stage was to test the knowledge of Junior high school students about folk tales, about the classification of fairy-tale genre, poetic of Russian and Tatar folk tales; the ability to analyze, to compare, to check the readiness of the moral-ethical categories of students in primary schools.

The purpose of formative stage of the experiment were: development of a concept of Russian and Tatar folk tales; the defining features of the content and poetics of Russian and Tatar magic, household tales and tales about animals; the formation of comparison skills of Russian and Tatar folk tales in the context of dialogue of cultures. We have developed a methodology for comparative study of Russian and Tatar folk tales in the 2nd grade of 
primary schools in the context of dialogue of cultures which contains 5 blocks of lessons of literary readings. The students of the 2 form of experimental class studied according to this methodology. Students of the $2 b$ of the control class were taught by the method of the textbook readings "School 2100" (Savinov, 2010)

The first block. (Lesson 1). Study of Russian folk tale "The frog Princess". Lesson-meeting with Vasilica the wise. The concept of a fairy tale. The issue of the tale. Miracle in the tale, fairy-tale hero, fabulous expressions. Creative presentation of the book cover. Competition of creative works of students.

The second block. (Lesson 1). Lesson-discussion on the comparative study of Russian folk fairy tale "the frog Princess" and Tatar folk fairy tale "Tan-Batyr". The concept about the plot, composition, the poetry of the fairy tales. The formation of comparison skills of fairy tales on the basis of the characteristics of heroes (Vasilisa the wise and tan-Batyr). Learning to make a comparative characteristics plan of fairy-tale characters.

The third block. (Lesson 1). Lesson-quiz as an active form of learning Russian and Tatar folk tales about animals "The cat and the Fox" and "The Fox and the Wolf". The formation of comparison skill of tales about animals on the basis of comparison of the plot, composition, morality of tales.

The fourth block. (Lesson 1). Game-lesson about comparative study of Russian and Tatar folk tales of everyday life "As the old man was demonical" and "the Tailor, the imp and the bear". The formation of comparison skill of fairy tales on the comparison basis of people's moral norms and values. The staging of fairy tales as a kind of creative activity of young learners.

The fifth block. (Lesson 1). Blitz tournament of folk tales experts. Formalizing of comparative analysis skill of the tales of two nations in the context of cultures dialogue (topic, system images, story, composition, idea educational potential of fairy tales). Creative competition of teams as a form of education of active ("qualified") reader. The competition for the best teller of tales. The competition for the best author of the fairy tale with continuing.

The purpose of the control stage of the experiment was to test the readiness of comparison skill of Russian and Tatar folk tales (theme, character, plot, idea); to determine the effectiveness of the methodology of Russian folk tales study in primary school in the context of cultures dialogue.

The results of this experiment suggest that the proposed methodology for the study of Russian folk tales at the lessons of literary reading contributes to the formation of "folk tale" concept, the literary development of primary school pupils, the identification of universal human content in Russian and Tatar folk tales of each national culture and specific to each national picture of the world" by the students of primary schools..

\section{Results}

The results of this experiment allow say that the proposed educational model of the formation of the" tale" concept on the basis of a comparative study of Russian and Tatar folk magic, everyday life tales and tales about animals is effective, providing a deep knowledge of primary class students. Introduction into educational process of methodical study models of Russian folk tales in the context of cultures dialogue at schools with native (non-Russian) language of the Republic of Tatarstan allows students to perceive deeper works of fantastic genre, contributes to a holistic comprehension of literary material by students, formation of literary associations culture.

The research confirmed the correctness of the hypotheses: 1) Comparative study of Russian and Tatar folk tales in the context of dialogue of cultures creates the necessary technical conditions for the formation by the younger students the ability to analyze, to compare, to classify, to generalize. 2) Using of active forms of learning (lesson-meeting with character, lesson tournament, lesson-quiz) with taking into account the perception and study of fairy tales by children of primary school age contributes to a deeper understanding of the national peculiarities of Russian and Tatar folk tales, the entirety of moral-ethical values of Russian and Tatar people.

Younger students ( 2 and class) learned to compare tales of Russian and Tatar people by the subject, ideological content, image system, poetics, and moral-ethical categories. Necessary speech and reading skills were formed by the students of experimental class. In the comparative study of fairy tales, a great attention was paid to the education of the moral qualities (kindness, hard work, patriotism, loyalty, responsibility).

\section{Discussions}

Dialogue is understood by B. C. Bibler as "a communication of the actual and / or potential cultures". The scientist gives some evidence. Firstly, "culture always exists in a simultaneous "space" of many cultures..." secondly, "time culture is always currently, today, in which communicate and have a dialogue all past and future cultures..." thirdly, "in this communication each culture actualizes itself as a separate culture, a distinctive, rounded, and inexhaustible in its uniqueness and eternity." Fourthly, the "dialogue of cultures... is like... the 
communion of persons" (Bibler, 1999).

In fairy tales of different Nations, according to Fraser, there is a "mythological community ...cultures"; on the basis of creative thinking of modern civilized man are the same myths (Frazier, 1923). Our study confirmed the idea K. Levi-Strauss: "tales keep the memory of the ancient myths, which have fallen into disuse" (Lévi-Strauss, 2011). In the content of Russian and Tatar folk tales can be traced most important archetypal images, reflecting, according to the viewpoint of K. Jung, the fundamental principle of existence: "mother", "father", "child", "shadow", "anim", "wise old man" (Jung, 1991). The research of F. Creuzer confirms the idea that the tale was a myth" (Creuzer, 1837). In their research Taylor suggested that modern culture contains unconsciously, rethought remains of primitive culture. The tale is a remnant of the primitive myth, says Taylor (Taylor, 1891).

Studying of Russian folk tales in the context of dialogue of cultures is one of the important problems of modern methodology. Studying of different nations' tales allows us know better our own culture, to understand another culture as our own (Zamaletdinov, 1999). Philosophical works of Gachev and works about ethodology of literature teaching of Akhmedzyanova are devoted to the problem of cultures dialogue. They study the "Dialogue of cultures as a process "of creative understanding" different cultures in time and in space, as comparing of different individualities and different points of view.

In the teacher's manual of M. Akhmetzyanov, "Study of the literary relations at Tatar school" the author summarized the materials of Russian-Tatar literary relationships and developed the methods of their use in the process of learning of some topics at secondary school. The author considers the features of creative thinking of students of the national school, which is formed under the influence of the native literature and is complicated by the primary aesthetic skills. She gave an important conclusion that the task of the teacher is to help pupils to overcome the "psychological barrier" in the perception of art works of other people. The teacher must find ways and methods of teaching that will help students to switch from one aesthetic system to another and will warn difficulties perception of Russian literature (Akhmetzyanov, 1979).

The study of works of literature in the context of dialogue of cultures, according to R. F. Mukhametshin, "helps us to see the common things in both literatures, and to realize the national identity of each of them, allows to overcome the defects of the traditional literary education of students in the bilingual education associated with a low level of awareness of their native literature and culture" (Mukhametshin, 2006).

Russian and Tatar culture, treating adaptive type of civilization and being in close proximity, converging as two dissimilar civilizations. But at the same time they belong to different national cultures. In the architectural style of the artistic thinking of the Tatar people manifested this trait as an external restraint and inner emotion, or in the words by Marietta Shaginyan, address "all passions inside as the window Of Muslim house"(nigmatullina, 1997)

Many critics have noted that the Tatars are characterized by some external severity, restraint of the senses with mental softness, sometimes till sentimentality. Tatar people do not express their feelings openly. "And sorrow, and joy the nation kept inside", internally trying to hide their feelings from others." Therefore, in the art of thinking of Tatars dominates associativity (Nigmatullin, 1997).

These important features of artistic thinking of Tatars must be taken into account in the methodology of teaching Russian folk tales at school with native (non-Russian) language learning in the context of dialogue of cultures", when there is a comparative study of Russian and Tatar folk tales. The process of creative thinking in Tatar folk tales is not as subtle movement of similar, almost identical associations, or, on the contrary, as the development of an entirely different, incompatible views converged on the colors, values, feeling a variation of the known motive.

In previous studies the problem of learning of Russian folk tales in the context of the dialogue of cultures at schools with native (non-Russian) language of studying was not the subject of special consideration.

\section{Conclusion}

Theoretical analysis of studies in philosophy, aesthetics, literary criticism, psychology, pedagogy related to the research topic, as well as results of experimental work allow to draw the following conclusions:

1) The theoretical basis of the formation of concepts about the Russian folk tales is the concept of continuity of the literary process and interaction of cultures of Russian and Tatar people in the context of dialogue of cultures.

2) The formation of concept about the Russian folk tale involves the creation and implementation of a methodological model based on personality-oriented approach.The main feature of the developed model is a systematic approach and the holistic organization of activities of students while by taking into account the 
artistic originality of Russian and Tatar folk tales: phasing of the tale concept formation; identifying in comparative analysis successive links in Russian and Tatar fairy tale in the context of dialogue of cultures.

3) Experimental implementation of educational models in the practice of school analysis, conducting a formative experiment, the mappings between source and target sections revealed that the proposed study of the system of formation of the concept of the tale is really effective, contributing to the formation of an active reader, and active and creative personality with independent thinking, the ability to distinguish the true values from the false. The proposed lessons system promotes the development of autonomy in the analysis of fairy tales of Russian and Tatar peoples, activating creative thinking of students, development of speech.

4) The use of active forms of teaching (lessons with the use of functional-role-playing game) in combination with taking into account the peculiarities of Russian folk tales studying at school with native (non-Russian) language learning contributes to the creation of students' positive motivation, which increases the efficiency of the impact literature.

The work is performed according to the Russian Government Program of Competitive Growth of Kazan Federal University

\section{Recommendations}

Materials of this article can be useful for teachers of higher educational institutions and primary school teachers in using of this technique of Russian and Tatar folk tales studying in the context of the dialogue of cultures.

\section{Acknowledgments}

The work is performed according to the Russian Government Program of Competitive Growth of Kazan Federal University.

\section{References}

Afanasyev, A. N. (1994). The poetic vision of the Slavs into nature (pp. 5-55). Moscow: Goslitizdat.

Ahmetzânov, M. G. (1979). Study of literary Tatar school relationships: A handbook for teachers (p. 129). Kazan: Tatar knizhnoe izdatelstvo.

Akhmetzyanova, A. I. (2014). Special and temporal elements of anticipation consistently of children with general speech. American Journal of Applied Sciences, 11(7), 1031-1035. http://dx.doi.org/10.3844/ajassp.2014.1031.1035

Bakhtin, M. M. (1986). Esthetic of literature creativity (p. 332). Moscow: Art.

Bibler, V. S. (1991). From science to the logic of culture: Two philosophical introductions in the twenty-first century (p. 299). Moscow.

Frazer, J. G. (1923). The primitive culture: Studies of the development of mythology, philosophy, religion, art and customs (p. 35). London: General Books LLC.

Gachev, G. D. (2009). Science and national cultures (p. 6). Rostov-on-Don: Publishing house of the Rostov University.

Greuzer, G. F. (1837). Symbolik und Mythologie der alten Volker, besonders der Griechen (p. 62). Leipzig: Leipzig und Darmstadt, Heyer und Leske.

Jung, C. G. (1991). Approach to the unconscious (p. 65). Moscow: Renaissance.

Levi-Strauss, K. (2001). Structural anthropology (p. 154). Moscow: Publishing house EKSMO-Press.

Meletinskiy, V. M. (1976). The poetics of myth (p. 204). Moscow: Education.

Mukhametshina, R. F. (2006). Literature studying in aspect of dialogue of cultures: Tutorial for teachers (p. 25). Kazan: Heter.

Nigmatullina, Y. G. (1997). Types of cultures and civilizations in the historical development of the Tatar and Russian literatures (p. 190). Kazan: Feng.

Propp, V. Y. (2000). Russian fairy tale (p. 76). Moscow: Labyrinth.

Savinov, E. S. (2010). Approximate main educational program of educational institution, Elementary school (p. 136). Moscow: Education.

Taylor, Э. В. (1891). The primitive culture, Studies of the development of mythology, philosophy, religion, art and customs (p. 234). Saint-Petersburg. 
Zamaletdinov, L. Sh. (1999). Plots and motives of the Tatar tales about animals (p. 59). Kazan: Rannur.

\section{Copyrights}

Copyright for this article is retained by the author(s), with first publication rights granted to the journal. This is an open-access article distributed under the terms and conditions of the Creative Commons Attribution license (http://creativecommons.org/licenses/by/3.0/). 